\title{
Futalognkosaurus dukei - ny megadinosaur fra Sen Kridt
}

\section{Af geolog Morten Leth Hjuler}

Fundet af en enorm halshvirvel i Patagonien, Argentina, blev startskuddet til udgravningen af en ny megadinosaur samt en usædvanligt detaljeret beskrivelse af et økosystem fra det Sene Kridt.

I GeologiskNyt nummer 4 præsenterede bagsidehistorien de mægtigste, kendte eksemplarer af alle tiders største, landlevende dyr: sauropoderne. I mellemtiden er endnu en kandidat til denne tungtvejende titel dukket op fra Argentina i form af det hidtil mest komplette skelet af en megadinosaur.

Eventyret startede i marts 2000 med fundet af en usædvanligt stor halshvirvel fra en sauropod i det nordvestlige Argentinas Neuquén-provins i Patagonien (se illustrationen til højre). Fundet af Futalognkosaurus dukei skulle blive startskuddet til udgravningen af mere end 1.000 plante- og dyrefossiler fra et terrestrisk (landbaseret) økosystem. Fossilerne er koncenteret i en 0,5 $\mathrm{m}$ tynd flodaflejring fortrinsvist bestående af sandog siltsten fra den nedre del af Øvre Kridt (Coniacien). Udgravningsområdet, som dækker et areal på omkring $400 \mathrm{~m}^{2}$, betegnes Futalognko-lokaliteten, og dets geologiske betydning har ført til oprettelsen af et udgravningscenter.

\section{Futalognkosaurus dukei}

Futalognko-lokalitetens mest spektakulære fund er det usædvanligt komplette skelet af den enorme sauropod, som dette efterår er blevet døbt Futalognkosaurus dukei. Slægtsnavnet er udledt fra mapuche-indianernes sprog, hvor futa betyder "enorm" og lognko betyder "anfører”; det græske saurus betyder "øgle"; altså: enorm anfører af øgler. Artsnavnet dukei hentyder til det nordamerikanske selskab Duke Energy Argentina Company, som finansierede udgravningen.

Indtil nu har den systematiske beskrivelse af megadinosaurer været baseret på fortolkningen af ganske få mere eller mindre velbevarede knogler, hvilket i vid udstrækning har gjort størrelsesestimater til kvalificeret gætværk. Men med det relativt komplette Futalognkosaurus dukei-skelet, som inkluderer over 20 hals- og ryghvirvler, flere ribben, korsben (sacrum), begge hofteben (ilium), skamben (pubis) og sædeben (ischium), kan en væsentlig del af dyrets dimensioner måles direkte på det fossile materiale. Desværre forbliver de eksakte dimensioner usikre, da alle fire ben og kranium mangler, og kun en halehvirvel var bevaret.

Futalognokosaurus dukei tilhører titanosaurerne, en gruppe af solidt byggede sauropoder, som dominerede i tidsrummet Mellem-Sen Kridt. Titanosaurerne afløste de jurassiske og tidligkretassiske sauropodfamilier, som inkluderede velkendte slægter som Diplodocus, Apatosaurus og Brachiosaurus.

Trods den manglede hale kan længden af Futalognokosaurus dukei med rimelig sikkerhed estimeres til 32-34 m, hvilket er en anelse kortere end slægtningene Argentinosaurus huinculensis og Puertasaurus reuili, begge $35 \mathrm{~m}$, hvis længdeestimater dog er baseret på væsentligt mindre fos-

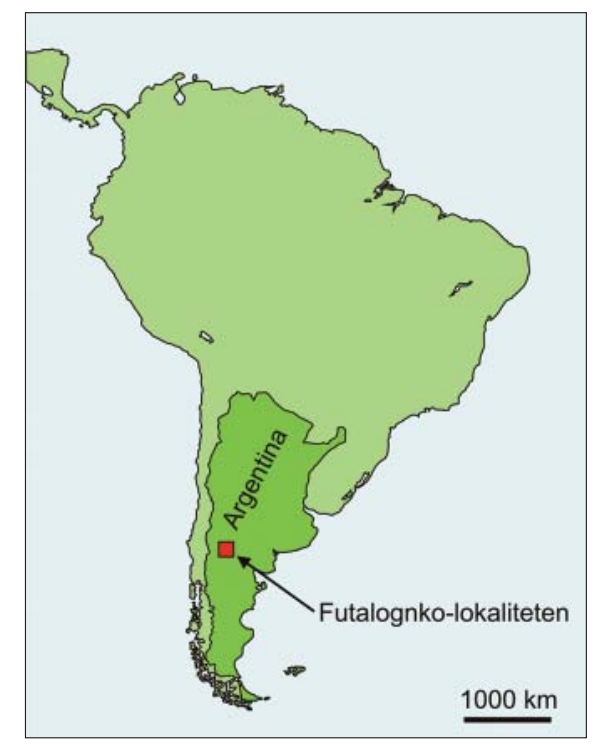

Futalognko-lokalitetens placering i Argentina. (Grafik: forfatteren)

silmateriale. Alle tre titanosaurer stammer fra Patagonien, en indikation på at sauropoderne udviklede særligt store slægter på det Sydamerikanske kontinent i tiden under og efter opsplitningen af det vestlige Gondwana (Sydamerika og Afrika).

Til sammenligning levede de største nordamerikanske sauropoder som fx brachiosauriden Sauroposeidon proteles (34 m lang, 17-18 m høj) og diplodociderne Seismosaurus hallorum (33 m lang) og Supersaurus vivianae (32-33 m lang) i det Sene Jura og Tidlige Kridt, altså i tiden op til titanosaurernes indtog. På længde og 


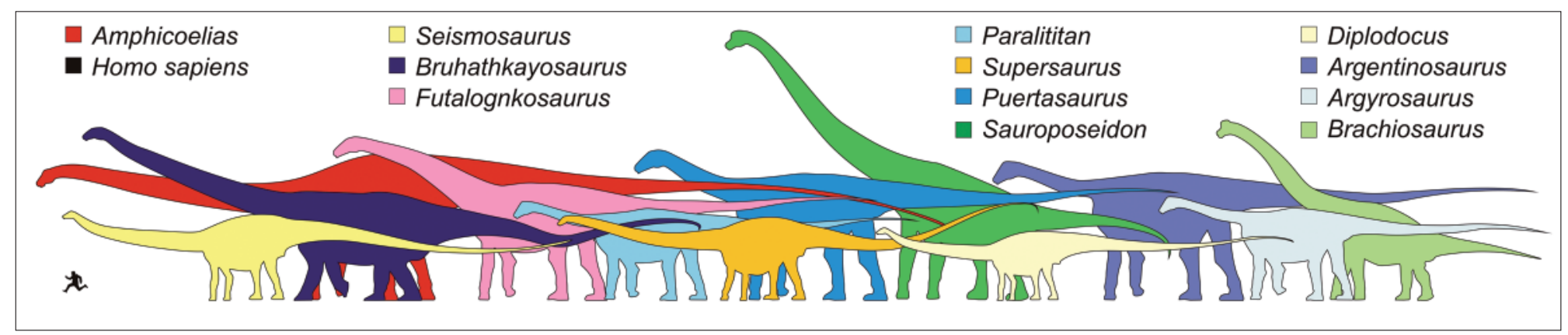

Anslået udformning og størrelse af de største kendte sauropoder sammenlignet med et $180 \mathrm{~cm}$ højt menneske. (Grafik: forfatteren)

højde kunne de nordamerikanske megadinosaurer måle sig med de yngre sydamerikanske titanosaurer, mens sidstnævntes vægt var væsentligt højere grundet en kraftigere kropsbygning. De største kendte dinosaurer med Futalognokosaurus dukei er samlet øverst på denne side.

\section{Patagoniens økosystem i Sen Kridt}

Futalognokosaurus dukei døde muligvis på en flodslette, hvorefter en voldsom oversvømmelse transporterede liget ud i en flod. Her udgjorde det enorme lig en effektiv barriere, og sammenskyllet organisk materiale ophobedes ved liget. På et tidspunkt ændre- des flodens løb, og Futalognokosaurus dukei samt det ophobede organiske materiale blev afsnøret i en hesteskoformet sø, hvor det iltfattige miljø forhindrede nedbrydningen af plante-og dyrerester.

En unik rigdom af plante- og dyrefossiler er blevet frigjort sideløbende med udgravningen af den store titanosaur. Blandt de udgravede fossiler fra lokaliteten findes rester fra adskillige dinosaurer, bl.a. (mindre) sauropoder og forskellige typer kødædende dinosaurer; også plantedele fra både nøgenog dækfrøede planter, fisk og de fossile efterladenskaber af en slægtning til nutidens krokodille - en flyveøgle med et estimeret vingefang på 6 m er også blevet udgravet.

Futalognko-lokaliteten er unik, da de righoldige, fossile informationer repræsenterer et ganske kort tidsrum og udgør et detaljeret øjebliksbillede af det Sene Kridt i Patagonien. For ca. 87 mio. år siden var Patagonien præget af et varmt, fugtigt klima afbrudt af tørre sæsoner. En mæandrerende flod løb gennem en skov domineret af dækfrøet vegetation med mindre indslag af nøgenfrøede planter. Området var beboet af store såvel som små kødædende dinosaurer samt de enorme sauropoder; faunaens andre krybdyr inkluderede skildpadder, flyveøgler og slægtninge til nutidens krokodiller.

\section{Kort nyt}

\section{Indlandsisen smelter}

Nye forskningsresultater fra Danmarks Rumcenter under DTU viser, at indlandsisen på Grønland smelter hurtigere, end videnskaben hidtil har antaget. I det sydøstlige Grønland kælver gletscherne hvert år, hvad der svarer til en kæmpe isterning på 6,5 $\mathrm{x}$ $6,5 \mathrm{~km}$.

Seniorforsker Abbas Shfaqut Khan fra Rumcentret og ansvarlig for forskningsprojektet oplyser, at der for øjeblikket smelter fire gange så meget indlandsis end for syv år siden.

Ritzau/SLJ

\section{Jordskælv på Sumatra}

20. september rystede et jordskælv, der blev målt til 6,7 på Richter-skalaen, det vestlige Sumatra i Indonesien. Ugen før blev samme område ramt af to jordskælv af lidt kraftigere styrke. Over 20 mennesker mistede da livet. I forbindelse med de nævnte jordskælv blev der ikke udsendt tsunami-advarsler. 